\title{
Why workers' turnover is so high: managed flexibility and the intermediary chain of China's migrant labor market
}

\author{
Zixi Liu* and Jianghuafeng Zhu
}

\author{
*Correspondence: liuzx06@gmail. \\ com \\ Xiamen University, School of \\ Sociology and Anthropology, 422th \\ Siming South Road, Siming District, \\ Xiamen, Fujian, China
}

\begin{abstract}
Looking at how the global factories organize and control their labor forces sustainably and effectively, a considerable number of studies have focused on the politics of production but have seldom discussed the organization of the labor market beyond the workplace. Based on fieldwork about labor recruitment in the manufacturing industry in City $\mathrm{W}$, this article analyzes the organizational ecology of the current labor market and its embedded institutional environment. It shows that to satisfy factories' demand for flexible labor, the organizational ecology of the labor market has developed an intermediary chain characterized by multilevel outsourcing, an elaborate division of labor, and constant internal competition and cooperation. Although the intermediary chain coordinates flexible production, its profit-making model and business strategies drive up labor costs, consistently aggravating labor turnover and constructing low-skilled labor force. Local government, enterprises, and workers are the three forces constituting the institutional environment that nurtures this intermediary chain. Each of them makes use of "flexibility" for their own interests, unintentionally increasing the risks to the production system.
\end{abstract}

Keywords: Intermediary chain, Labor market, Flexibility, Labor shortage

\section{Introduction}

Since the reform and opening-up, China has transformed itself into the global factory; its manufacturing industries have experienced booming development owing to cheap labor. In the twenty-first century, China has the largest working-class population all around the world. Recently, however, China began to confront labor shortages. Statistics show that since 2013, the absolute size of the labor force has continuously decreased, and that in 2015, the working-age population stopped growing, indicating the disappearance of China's demographic dividend and that labor shortages will continue. At the same time, there has been a corresponding growth in labor costs and worker turnover. In 2011, wages in the manufacturing industry increased by $13 \%$ on average, while workers' turnover rate reached $35.6 \%$, ranking at the top among 11 surveyed industries. In 2015, manufacturing

(c) The Author(s). 2020 Open Access This article is licensed under a Creative Commons Attribution 4.0 International License, which permits use, sharing, adaptation, distribution and reproduction in any medium or format, as long as you give appropriate credit to the original author(s) and the source, provide a link to the Creative Commons licence, and indicate if changes were made. The images or other third party material in this article are included in the article's Creative Commons licence, unless indicated otherwise in a credit line to the material. If material is not included in the article's Creative Commons licence and your intended use is not permitted by statutory regulation or exceeds the permitted use, you will need to obtain permission directly from the copyright holder. To view a copy of this licence, visit http://creativecommons.org/licenses/by/4.0/. 
companies increased workers' wages by $7.1 \%$ on average, with a turnover rate of $28.9 \%$ which remained the highest among 11 industries. ${ }^{1}$ Extreme difficulties in recruiting and retaining workers are serious problems for manufacturing enterprises in China.

Labor shortages have raised broad concerns in academia. Some scholars analyze labor shortages from the perspective of labor demography. For example, Fang Cai and his colleague find three leading causes of labor shortages: a smaller working-age population after a dramatic decline in the birth rate, high migration costs brought about by the household registration system, and excessively low wages due to insufficient profit margins for companies (Cai and Wang 2005; Cai 2010). Chunguang Wang (2001) finds that intergenerational changes in life pursuits and identity are likely to influence urban employment. Linping Liu et al. (2006) notes that excessively low wages and dependence on personal ties lead to a high turnover rate of migrant workers, which makes labor recruitment more challenging for enterprises.

Other scholars have attempted to understand labor shortages by employing Polanyi's counter-movement for social protection. For instance, Meng and Li (2013) argue that since 2004, the significance of labor shortages in the Pearl River Delta embodies a spontaneous workers' resistance to the over-commodification of labor. Yuan Shen (2006) points out that labor shortages reveal certain structural power of a new working-class that is "voting with their feet" to strive for higher wages and better working conditions. Liu and Cui (2012) argues that the existing institutions are incapable of providing rural-migrant workers with stable job prospects and guarantees of rights and interests. Therefore, individuals express their dissatisfaction with the "dictatorship of the market." Labor shortages are not only a manifestation of rebalancing labor relations but also a way of reintegrating the market into society.

These studies have revealed concrete reasons and conditions for the occurrence of labor shortages in China but failed to answer how manufacturing companies meet their labor demands and sustain production in the face of severe labor shortages and unbalanced labor supply-demand relationships. The tension between structural labor shortages and sustained operations of the global factories remains to be investigated. From a theoretical perspective of the neoclassical market model, demographic transition, intergenerational changes, and the rate of labor mobility could undoubtedly influence the shift in the supply curve for labor. In this regard, scholars insist that a labor shortage results from underpricing the labor force. Discussions on "voting with their feet" and "spontaneous resistance," however, attribute labor shortages to an attempt to resist the excessive expansion of the market, a sign of decommodification of labor. Thus, there is a theoretical gap between labor decommodification theory and labor price theory. How can the labor market maintain its price system? What strategies are employed to sustain the commodification of labor when confronting the countermovement?

To address the practical problem and the theoretical gap, this article explores the organizational ecology of the labor market, its institutional environment, and the related parties. We argue that they function together to control the labor market and supply a large group of "flexible" workers. The reproduction of flexibility is the locus to

${ }^{1}$ Statistics extracted from the 2015 White Paper on China's Remuneration (http://www. puxinhr.com/content /5 20160105150550.shtml). 
understand why labor shortages do not lead to industrial upgrading or substantial improvement in labor protection.

This article includes two parts. The first part focuses on the organizational ecology of the current labor market in the manufacturing industry, with particular emphasis on the role, relationships, and behavior patterns of labor intermediaries, discussing the reasons and conditions for why labor intermediaries could become central in labor supply. What is the organizational chain and structure formed by various labor agencies? The second part of the analysis concentrates on social forces in making this organizational ecology. More specifically, what is the institutional environment in which the labor market is embedded? What is the mechanism by which various parties actively or passively participate in such an institutional formation? What are the possible consequences of such an institutional environment that reproduces flexibility in the production system?

\section{Literature review}

\section{Labor market: abstract and concrete}

How to understand the property and function of the labor market is an important question in the sociology of labor. There are two schools of thought, Marx and Polanyi. In Marx's view, the labor market is merely a specific sector of the commodity market since labor has gone through pervasive and thorough commodification, no different from other means of production. Owners of labor and owners of capital encounter and deal with each other in the market as commodity owners with equal status, but how they meet each other and which intermediate link exists are not important. Marx's labor market is highly abstract and could operate autonomously according to pure economic laws due to the "dual freedom" of labor. He emphasized labor process control after the purchase of labor rather than the configuration of the labor market before the purchase.

For Polanyi (2006), however, such "completely commodified labor" and "completely unregulated labor markets" do not exist; they are both utopian assumptions. In his view, the commodity image of labor is entirely fictitious. Labor is only another name for innate human activities that are not produced for sale and cannot be detached or stored apart from other parts of life. When an unconstrained market attempts to expand to these fictitious goods, it will arouse the self-protection movement of society, a joint force of various measures and policies to inhibit labor-related market behavior and embed the market in social regulation. Correspondingly, the operation of the labor market where transactions and circulations of fictitious commodities occur is also embedded in a series of institutional arrangements. In fact, it is by the state's intervention and institutional design that labor can be successfully virtualized and freely traded and that an orderly labor market is established. Therefore, the labor market is highly concrete and is engraved with specific institutional imprints and localized social characteristics.

Since the 1970s, there has been increasing discussion of the labor market as a concrete product of social construction. Some scholars begin with studying particularities of labor as a commodity and argue that workers are neither a carrier of abstract labor nor a homogenized commodity. Prevalent and thorough commodification of labor does not exist more than an abstract labor market does. For example, Burawoy (1979) 
researched the game of "making out" and revealed the significance of the subjectivity of workers in the labor control process. He notes that capitalists can capture and conceal surplus value because of workers' active participation in exploiting themselves and the "consent" to exploitation made within the ideological mechanism of production.

Based on historical analysis, Roediger (1991) points out that the consciousness of the working class from 1800 to 1865 was based on race rather than class. White workers actively emphasized their white and non-slave status to distance themselves from black workers. The racial division between white and black workers far outweighed the unity aroused by the common mode of production. Lee (1995) puts forward that the means of control over the labor process is closely related to how the labor market is organized. It is through the relationship with fellow villagers that Shenzhen female workers entered the factory and were controlled by the managers. In contrast, Hong Kong female workers were dependent on families and relatives so that managers consciously helped them fulfill their family responsibilities. Another group of scholars directly portrays the embeddedness of the labor market. They describe how diverse structures and employment relationships of the labor market were produced by social forces such as history, culture, and institutions. Considering the questions and research objects in this article, we review the following literature on informal employment and intermediary organizations of the labor market.

\section{Informal employment: the rise and diversity}

Since the late 1970s, Fordism featured by large-scale, formal, and stable employment has come into crisis. The post-Fordism regime is characterized by reducing employment benefits, rejecting collective bargaining, impairing worker unions, and lowering wages, as well as substantially replacing full-time employment with part-time or outsourced workers. It ensures a self-regulating market. Thus, the post-Fordism fostered the informality of the employment relations (Xie 2007). From a legal perspective, informal employment is reflected in the absence of a formal and legally binding labor contract between the employer and the employee (Wu and Cai 2006). Informal workers tend to suffer from low wages and lack of job protection, social security, and social welfare, with no protection under other institutional arrangements (International Labor Organization 2002).

With the globalization of production and distribution networks, this informality has become increasingly diversified and flexible, which is reflected in various forms of employment, such as outsourced workers, rush workers, student workers, and dispatch workers.

Guoxiong Xie (1989) summarizes in detail the characteristics of outsourced workers who were not recognized as having any employment relationship with employer companies or any labor rights coupled with employment. Outsourced workers tend to work at home with no direct control over their labor process by the factory but instead by the agent control from the outsourcing network. Yan Huang (2012) examines rush workers in the manufacturing industry in China's coastal areas. He argues that these workers intentionally abandoned formal factory employment but undertook short-term work and orders from outsourcing factories, actively cooperating with the operation of the "order economy" and the outsourcing industry. Pun and Koo (2015) note that, 
through internships, vocational education in China was making students into a new generation of cheap labor and that this low-wage, easily exploited student workers have become a vital source of labor to maintain the "global factory." Zheng et al. (2015) find "everyone can be a boss" game in small garment factories as a means of labor control. Participation in the game convinces workers that low wages, high labor intensity, and lack of labor protection are necessary for the primitive accumulation of capital. It also blurs the identity of workers and employers. So, playing the boss game survives small workshops in urban villages.

In summary, the above studies on diversified patterns of employment have explored the profound impact of the global outsourcing system on workers' identity, benefits, and labor processes; nevertheless, they have not emphasized the intermediate links between workers and factories. As dispatch labor has become highly prevalent and institutionalized at present, various types of intermediary organizations now comprise the organizational force for mass production of informal labor and are an important basis for the establishment of informal employment relations.

\section{Labor market intermediaries: role and impact}

Labor market intermediaries (LMIs) refer to entities or institutions that carry out intermediary activities between workers and enterprises, including facilitating the matching between job seekers and enterprises as well as resolving conflicts between them (Autor 2009). There are various classifications for LMIs, and Autor (2007) is based on market functions and service objects. According to market functions, LMIs can be divided into four categories: information provision, worker-side adverse selection, firm-side adverse selection, and collective action. According to service objects, LMIs can be divided into three categories: services for both firms and workers, services for firms only, and services for workers only. In addition to the above categories, the "relationship network" to some extent is also a type of LMI since informal social networks (not formal market channels) play an important role in the job-hunting process (Granovetter 1973, 1974).

Some scholars have conducted a nuanced analysis of the role of LMIs. Dongxu Liu (2016) examines the "foreman system," an organizational model of Yi ethnic workers in the Pearl River Delta, and vividly described the operation of each link in this system, including the big foreman, small foreman, shift leader, etc. He analyzes how the "foreman system" responded to and reproduced the marginalization of Yi workers in the labor market. Biao Xiang (2012) reveals "body shopping," a global labor allocation and management system centered in India, and analyzes the critical role of the "body shop" in this system. He describes how body shops, different from traditional agencies, recruited Indian IT workers and supplied them to enterprise projects overseas through ways of "sitting on the bench," work visa applications, and accommodation arrangements. The procedures and strategies of body shops were deeply rooted in the internal fabric of Indian society and echoed the instability of global capitalism.

From a legal perspective in China, LMIs comprise labor dispatch organizations and labor intermediary organizations. The essential difference between them is that labor dispatch organizations are obliged to sign labor contracts and establish labor relations with dispatched workers under Labor Law and Labor Contract Law, while labor intermediary organizations primarily provide information services to enterprises and 
workers and have no labor contracts or establish labor relations with the workers (Wu and Zhang 2008). Nevertheless, according to some investigations, the distinction between their actual operations is not that explicit. Labor dispatch organizations are not confined to employment management but are also involved in the recruitment business and sometimes even charge fees for applicants. Labor intermediary organizations serve not only as messengers between enterprises and workers but also as brokers between labor dispatch organizations and workers.

Although LMIs can facilitate employment and integration of workers into enterprises, they will exacerbate existing inequality to derive economic benefits (Stovel and Shaw 2012). Migrant workers are particularly vulnerable in such unequal relationships when intermediary agents isolate these workers from their employers by language, ethnicity, and legal boundaries, continuously compounding their weaknesses (López-Sanders 2014). Some scholarly analysis of the labor dispatch system in China also suggests other possible adverse effects of LMIs. Decheng Xie (2013) points out that from a normative perspective, the legal status and basis of the current labor dispatch system require further clarification, within which problems are concentrated on aspects of labor contracts, social insurance, and equal pay for equal work.

The above studies have generated insights into the LMIs, yet there are still three shortcomings. First, an in-depth and nuanced discussion about LMIs is needed because LMIs have gradually evolved into a monopolistic power in labor allocation when labor dispatch and labor outsourcing are the mainstream patterns of employment in the manufacturing industry. In addition, LMIs are not a static type or abstract legal concept but a cluster of constantly dividing, evolving organizations with internal structures and relationships that are becoming increasingly complicated. Second, although some scholars have pointed out illegal employment in the process of labor dispatch, few empirical studies discussed the empirical basis of these problems. For instance, how laws are, in practice, affected by structural forces such as the production system and labor management system. It is no wonder that solutions existing only on the normative boundary between legality and illegality fail to solve those problems. Third, workers are not passive or have no agency but instead possess a certain ability to resist. How can they "willingly" become a labor force that is unrestrictedly allocated by LMIs and factories, even under the circumstances of impaired rights and institutional segmentation? How can LMIs control and manipulate workers' consent and dissatisfaction? These questions remain to be investigated.

This article focuses on recruitment, which is the intermediate link between individual workers and factories and highlights the vital role of LMIs in this process. Regarding LMIs as a heterogeneous organizational group, this research examines its internal structure and operation, analyzes its embedded institutional environment, and eventually provides thorough insights into the production of the intermediary chain.

\section{Methodology and data}

The selection of City W as the field site is based on three reasons. First, located in the Yangzi Delta, the coastal City W is a microcosm of the global production in order economy; its manufacturing industry is highly dependent on the global market and exportation. Second, the majority of local manufacturing companies are international subcontracting manufacturers with characteristics of dependence on foreign orders, which 
means a clear correlation between labor demand, order fluctuation, and high worker turnover. The number of employees in manufacturing companies has surpassed that of other industries, accounting for $40-50 \%$ of local labor employment. ${ }^{2}$ Last but not least, labor dispatch and outsourcing are two main employment relationships in this area. Large and numerous, within the area of Industrial Park District alone, there exist 150 intermediary companies, not to mention tens of thousands of labor agencies and scalpers. $^{3}$

Notably, the categorization of intermediary organizations in this article is based on empirical observation rather than legal regulations. "Intermediary organization" is a generic name of all organizations and individuals engaging in the intermediary business, including service companies, labor agencies, and scalpers. Service companies consist of human resources, services companies, and labor dispatching companies. They are supposed to sign labor contracts with workers under the Labor Law, with registered capital of no less than 2 million Yuan. "Labor agency" refers to those physical stores where workers could find available jobs. Compared with service companies, they have a smaller scope of the business, no contracts with workers, and are not subjected to the Labor Law. Scalpers usually serve as information transmitters among job seekers, labor agencies, and service companies. In the matter of personal practice, they have no regular place of business or any qualification certificate.

Since May 2018, we have conducted fieldwork on the labor intermediary operation and the process of labor recruitment. We first made contact with the director of one major service company and gradually met with other intermediary organizations by employing the "snowball method," ensuring that all types of intermediary organizations were covered. With the assistance of the workers' network, one of the authors participated personally in labor recruitment as well as factory work, acquiring substantial knowledge of workers' situations and general difficulties in their unsettled life. Furthermore, we conducted in-depth interviews with HR managers from several factories with which intermediary organizations had business. We also interviewed government officials, especially officials from the Human Resources and Social Security Bureau and its affiliated department-the Labor and Social Security Inspection Team-which were directly in charge of intermediary organizations and labor conflicts.

Most job seekers were young, with less than high school education. They came from neighboring cities; local people were seldom seen. Low-skilled work in factories was the only option available to these young people who had little information about the job market and intermediary organizations. Staff in intermediary organizations was mostly middle-aged with less education and were from the surrounding cities. For most intermediary business people, becoming rich was a realistic goal as many of them had done so, which was a sharp contrast to those young workers.

\section{Intermediary chain as organizational ecology}

In a broad sense, factories recruit workers through direct recruitment, home fellow recommendation, labor transfer, labor development, intermediary agents, etc. (Liu 2016). However, the human resources departments of the enterprises entrust labor companies

${ }^{2}$ Data taken from the Report on the Supply and Demand Analysis of Human Resources Market in the third quarter of 2018 in City W.

${ }^{3}$ Data acquired from the internal statistical report of 2017 provided by the local government authority. 
with recruitment rather than direct recruitment due to the high but fluctuating demand for workers, labor shortages, and high worker turnover. Labor service companies do not finish recruitment independently but rely on multilevel intermediaries of different types and sizes. Labor service companies are the core of the intermediary chain of recruitment. The labor service companies outsource recruitment businesses to intermediary organizations that then re-outsource to lower levels of the chain. Whether job seekers obtain jobs by personal job hunting or via a nonlocal foreman or vocational school in City W, they have to go through a long intermediary chain. Therefore, the intermediary chain in recruitment has become the main channel for labor allocation. This section describes the process and characteristics of the recruitment chain and explains how it could have such evident effects on the labor market.

\section{Recruitment through the labor intermediary chain}

As shown in Fig. 1, employers could not buy labor directly from the labor market but through a complex chain of recruitment. Upstream employers and downstream job seekers in the chain are separated by three levels of intermediaries, namely labor service companies, scalpers, and labor agencies, each of which is independent. Besides, scalpers fall into two categories, big scalpers and small scalpers, by the standard of social background and business capacity. Big scalpers have more abundant social capital and prevail over small scalpers in terms of resources and capabilities. From the perspective of information, employment information flows from upstream employers to different levels of intermediaries along the chain. It is finally posted on the bulletin board in front of agency stores to inform the job seekers. From the perspective of labor flow, job seekers, either as individuals or members of an organization, are approached first at agency stores. Then, the small scalpers send them to a transit place. Next, the big scalpers arrange the vehicles for transferring these potential workers to the labor service companies. Finally, labor service companies settle them into specific factory jobs. Any job seeker who ultimately obtains factory work must go through the four-stage handover process, in which each intermediary plays a particular role.

The first stage of handover is completed between the foreman ${ }^{4}$ and the labor intermediary. The foreman, who has organized a group of job seekers relying on his or her social network, contacts the labor intermediary and sends the workers to one of the agency stores as required. The job seekers are asked to register their information by the staff of this labor agency. Then, the second stage of handover begins when the scalpers start to take over from the labor agency store. The small scalper is responsible for summarizing information and providing transportation to transfer the job seekers to the big scalper. Next, the big scalper gathers the job seekers and transfers them to the labor service company, completing the third stage of handover. After the interview and medical check-up required by the labor service company, the job seekers sign labor contracts with this company and are finally sent to the employers who settle them into workplaces, which is the fourth stage of handover. If a labor agency has not yet set up business ties with a worker's preferred employer, the agency will refer the worker to

${ }^{4}$ While it is widely acknowledged that the labor market intermediaries are divided into three sections, the role of "foreman" is not specified in the intermediary chain. 


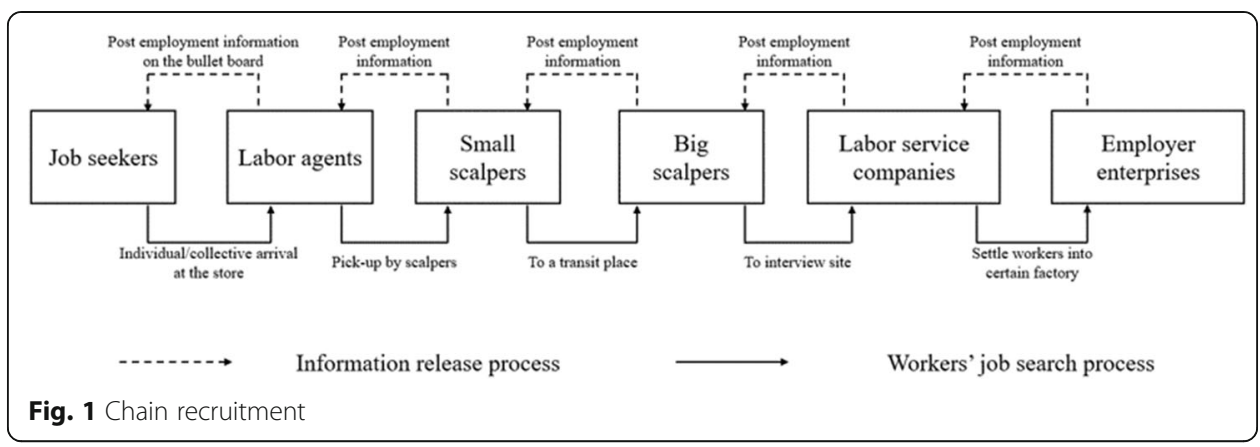

another labor agency that can provide access to the job. Then the stages of handover continue along the chain.

Therefore, labor agencies, scalpers, and labor service companies form an intermediary chain with a division of labor and various forms of cooperation. Since any form of cooperation is not exclusive from others, on the one hand, each node of the intermediary chain can be occupied by different intermediaries, and competitions often occur between these alternatives. On the other hand, these intermediaries establish cooperative relationships spontaneously and do not create any necessary boundary between the nodes in the chain. Therefore, the pressing questions are as follows: To what extent does this intermediary chain remain stable, and how can cooperation and competition concur in this case? These questions are related to the formation and reproduction of order in the organizational ecology of the labor market.

\section{Cooperation and competition between intermediaries}

The precondition for the intermediary chain to function is that various intermediaries can work together. First, the labor service company signs a worker-recruitment contract with an employer, but does not conduct the recruitment independently; instead, it actively outsources the hiring tasks to scalpers and labor agencies who acquire potential workers. This model of the outsourcing-acquisition relationship is beneficial to the labor service company. On the one hand, many scalpers and labor agencies could help the labor service company expand the recruitment network, searching and organizing the labor forces effectively. On the other hand, most labor agencies and scalpers working individually or in small groups are highly mobile and difficult to regulate. So they can avoid fixed pricing and adjust labor prices dynamically, thereby reducing the recruitment cost for the labor service company. Second, while the labor service company has signed a formal contract with the employer, biding them legally, labor agencies and scalpers remain informal and flexible in recruiting without contracting to either the employer or the labor service company. This formal-informal arrangement not only legitimizes the recruitment procedure but also substantially guarantees the efficiency of hiring. This method of dissociating employers from workers in labor contracts makes full use of the advantages of different intermediary organizations, creating a win-win situation where every function is performed fully and concordantly.

However, cooperation within the intermediary chain is also accompanied by competition between labor service companies and between the labor service company and the 
scalper (or labor agency). On the one hand, the labor service company must compete for the agential hiring business with other local rivals. With plenty of options available, the factory regards as necessary the agent's ability to engage and organize labor on a large scale. By this standard, it chooses only a few out of many labor service companies to work with; a labor service company unable to provide enough workers would lose this client. Moreover, labor service companies also compete to create a better reputation among workers. The kind of job offered by factories is related to the number of workers that the labor service company has provided. Therefore, for a labor service company, it establishes a reputation by sending more workers.

On the other hand, every intermediary in the chain intends to compete for the best collaborator. The labor service company will seek more competent scalpers or labor agencies if its current partners are unable to provide enough workers. For the same reason, scalpers and labor agencies would also try to develop business ties with other labor service companies if they have not received full payment from the current one. Moreover, intermediaries in different nodes of the chain compete for their scopes and boundaries of business. A hiring platform once attempted to break the intermediary chain by connecting workers directly to factories. However, it is incredibly costly to transform the current organizational ecology, especially with the collective resistance from organizations downstream of the intermediary chain. Therefore, for intermediaries in the recruitment chain, the competition on boundaries is far less intense than the competition on business capabilities.

\section{Spatial structure of chain recruitment}

Chain recruitment takes place in a specific spatial structure that reflects the division of labor as well as operational characteristics of the intermediary organization. To a certain extent, the spatial structure improves the stability of the intermediary chain. Chain recruitment has been unfolding along Street $\mathrm{T}$ partly because of the convenient transportation of the locale, which is easy for handovers of job seekers. The intermediary organizations spontaneously developed an atypical human resource market along Street $\mathrm{T}$. The right side of the street has lanes occupied by more than 100 scalpers and stores of labor agencies. As soon as job seekers enter the lanes, a staff of labor agencies incessantly accosts them and offer hiring information. If someone accepts the help, the staff counts him or her as the labor agency's recruitment. Then, this job seeker waits until a scalper shows up and brings him or her to the left side of the street, where labor transfer and handover takes place. Every day from 11:00 am to 1:00 pm, agencies and scalpers bring job seekers to the temporary booths of labor service companies; then, a staff of labor service companies registered and counted the job seekers. Later, when the number reaches a certain amount, a vehicle takes the job seekers to labor service companies for interviews. In fact, the left side of the street is literally clogged with waiting job seekers, labor agents, and scalpers, as well as vans for labor transporting. Besides, some vendors are gathering around, and many of them collaborate with labor service companies, taking ID photos of and selling pens to job seekers.

In such a spatial structure, it is almost impossible for a newcomer to find a job by himself or herself. Job seekers do not have any access to factories and thus cannot verify hiring information in person. Instead, they can only choose a labor agency based on 
their current experience, and passively become the labor commodity handed over and transported by intermediaries. The labor service companies, before the last stage of handovers, do not necessarily disclose any detailed job information to job seekers but merely regard them as laborers acquired, collecting ID cards, registering names, and employment preference. What the labor service companies care most about is not labor skill or personal situation but who or which agency sends them here so that they can set a price and pay the charge accordingly.

As described above, these are routine operations of the labor intermediary chain. Monotonous and unskilled as intermediary jobs may seem, they are actually very profitable. We have to wonder: what is the profit-making model of the intermediary chain? Where is the profit from?

\section{"Cashback" and intermediary chain for seasonal production}

Under the pattern of global production, manufacturers must orient production to orders from seasonal international markets. For the electronics industry in City W, April to June is the slack season, during which the factories need fewer workers; August to October is the busy season when factories substantially increase their needs for labor. In this case, factories turn to labor service companies for recruitment, building a large labor force of temporary employment. Before 2014, the "dispatched workers," who were hired into factories through labor service companies, received much lower pay than formal workers and can be laid off at any time. However, since 2014, the Interim Provisions on Labor Dispatch regulates that the number of dispatched workers must be within $10 \%$ of total labor in any factory. ${ }^{5}$ Thereafter, the "outsourced workers," also hired through labor service companies, have replaced the "dispatched workers" as the majority of labor for factories, accounting for approximately $70 \%$ of workers.

To clarify the concepts, the "outsourced worker" is distinguished from the "dispatched worker" in Chinese laws. From the perspective of management, the outsourced workers are directly supervised by the labor service companies, while the dispatched workers are managed by the factories. From the contract perspective, the object of labor outsourcing is the "project" that the labor service company should complete. A factory pays the company administrative fee according to the progress of the "project." The object of labor dispatching is the "labor" needed in a project. The factory pays the company based on how much labor is used. Legally, labor outsourcing is subjected to the Contract Law, and accordingly, factories do not bear the responsibility for any problem of outsourced workers. Labor dispatching is subjected to the Labor Contract Law, and hence, factories assume joint liability with the labor service company for compensation if any damage is caused to dispatched workers (Liu 2014; Zhou 2012). As labor outsourcing has not yet been clearly defined in law, it is used as a disguised form of labor dispatching. ${ }^{6}$

\footnotetext{
${ }^{5}$ As stipulated in Article 28 under the Provisional Regulations on Labor Dispatching, "When the number of dispatched laborers of the employing unit exceeds its total laborers by $10 \%$ before the implementation of the regulations, the employment plan should be re-adjusted and lowered to the stipulated percentage within 2 years since the implementation date of the regulations."

"Fake outsourcing and true dispatching" can be defined as the no difference in the outsourced personnel, remuneration, workplace, and work content after changing labor dispatching to labor outsourcing, except for the labor contract, personnel attribution, settlement method, and management model, etc. (Liu 2014).
} 
In addition to a regular payment, "cashback" is another important payment that serves as a profit-making mechanism of the intermediary chain and a key to maintaining the flexible production. Now, we explain the mechanism of "cashback."

\section{"Cashback": a strong incentive for intermediary organizations}

Labor shortages, in parallel with the fluctuating pattern of seasonal production, increasingly lead to difficulty in recruitment, especially during the busy season. It has become the major task for labor service companies to recruit temporary workers to meet the employers' need for workforce flexibility. In this context, "cashback" has emerged as a prevalent incentive for labor service companies to attract workers.

"Cashback," also known as the "returned money," is a sum of money paid by the labor service company to workers as an informal reward aside from formal wages. ${ }^{7}$ This incentive has three characteristics. First, the amount of "cashback" is highly related to the production season. As shown in Fig. 2, "cashback" fluctuates throughout a year, with the lowest in June, the highest in October, and a difference of 3500 Yuan. Since its fluctuation is directly linked to the seasonal production, "cashback" could be the strongest sign of labor demand. In this sense, the rise of "cashback" could foretell the coming of a peak season with increasing labor demand. Second, the amount of "cashback" varies from factory to factory, closely related to the characteristic of the factory itself. In other words, "cashback" is relatively lower in factories with relatively better employment packages for workers and higher in those without. Third, "cashback" is only given to eligible workers who meet specific requirements, such as working in a factory for more than 45 days without unexcused absence or rule violations. "Cashback" is a one-time payment.

The distribution of "cashback" goes through five steps, from the production line leader to the factory manager, to the labor service company, to scalper, and to labor agency, until the money, at last, reaches workers' hands. First, the line leader checks everyone's workload and hands in a list of names of qualified workers to the manager. Then, the manager gives the "cashback" and the list to the labor service company. Next, the labor service company pays the "cashback" directly into the scalper's bank account. The scalper transfers the money to the labor agency's account. Eventually, the labor agency distributes the "cashback" to every worker. With the "cashback," labor service companies manage to attract enough workers and indirectly control their workloads in factories. At the same time, scalpers and labor agencies can also make a profit from hunting and organizing labor. In this sense, "cashback" becomes a mechanism by which the labor intermediary chain works and plays a vital role in shaping the labor market. Further questions to answer are as follows: Where do labor service companies obtain money to give the "cashback?" How could the intermediary organizations in the chain make profits?

The profit-making model of labor service companies, labor brokers, and scalpers Source of "cashback": the profit-making model of labor service companies

The payment from factories to labor service companies includes two parts: management fees and rewards. Management fees refer to the overall charge for services,

${ }^{7}$ There is no formal definition for "cash back," and this article defines "cashback" based on interview data. 


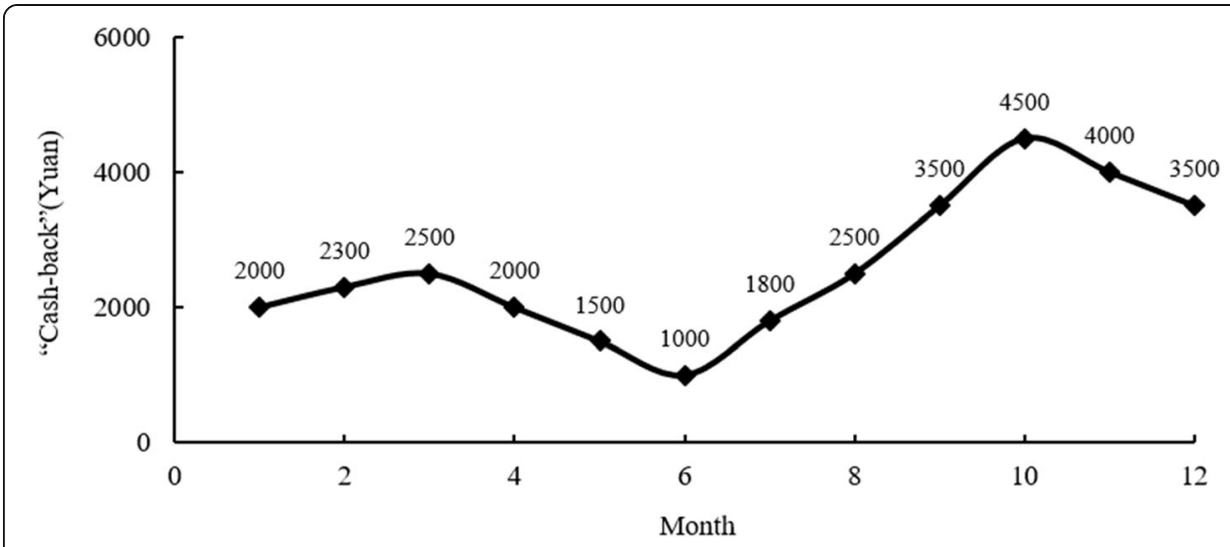

Fig. 2 "Cashback" seasonal fluctuations. The amount of "cashback" is roughly the monthly average, and the data come from the internal statistics of labor service companies

including advertisement, recruitment, training, payroll management, and dispute mediation. If the worker turnover rate is low, the management fee would be a fixed amount of money ranging from 100 to 500 Yuan per person per month. ${ }^{8}$ In other words, the management fee is calculated partly based on the length of time someone works for the factory; the longer the workers continue, the higher the fee the labor service companies charge. In addition, the labor service companies receive rewards from factories as an extra incentive for recruiting workers, depending on what proportion of labor demand has been satisfied by the labor service company.

It is noteworthy that the detailed "labor demand" is never fixed in the contract between factories and labor service companies; instead, it is only vaguely expressed as "providing labor forces according to the market demand, and the rewards could be secured if the company provides a certain proportion of the needed workforce." ${ }^{\prime 9}$ Also, at the beginning of each year, the factories issue a sheet of labor demand to labor service companies, but the labor demand does not appear on the contract, just as a reference. Because the factories' demand for labor is changing throughout the year, labor service companies have to adjust their recruitment accordingly based on the variation of turnover rate and production season. Therefore, the labor service companies act as a buffer for factories' demand for flexible labor.

To balance the risks borne by labor service companies due to their fluctuating demand for labor, factories will reward labor service companies according to the extent to which the services meet the factories' employment needs. In other words, the reward is not based on how many workers they recruit but on the extent to which the factories' demand for labor force is matched by the recruitment of the labor service companies. A full reward would be given to a labor service company if the aggregate demand was entirely met. Otherwise, the reward would be calculated according to the ratio of the recruitment number to the total demand for labor.

\footnotetext{
${ }^{8}$ This standard is the general charging standard for labor dispatching at present. However, for a large amount of labor outsourcing in the market, the labor company also charges according to this fee standard, which is calculated based on the size of the labor force. It proves the existence of the "fake outsourcing and true dispatching" phenomenon in the market.

9"Labor demand" and the corresponding rewards are not included in the labor outsourcing contract and are not specified in the labor dispatching agreement.
} 
In addition to management fees and rewards from factories, labor service companies also make profits from workers' interview fees and social security contributions. Different from the intermediary fee (which is free of charge in many labor service companies), the interview fee refers to the money the workers have to pay for taking ID photos and buying pens when they are preparing for interviews with labor service companies. On the other hand, labor service companies also pocket their social security contribution for workers as extra profit. Two reasons make their misappropriation possible. First, since outsourced workers hardly have any chance to become formal workers, the labor service companies do not pay the social security contribution for them but ask them to sign a statement claiming that they voluntarily refused it. Second, for the dispatched workers, although the labor service companies are obliged to pay social security contributions for them, the workers have to go through 3-month probation, during which the companies often default on this contribution and secretly pocket it as profits. During the busy season, this sum of money could be convenient as a part of "cashback."

In summary, labor service companies make profits from management fees, rewards from factories, interview fees, and social security contributions. These sources of profit are also the sources of "cashback"; the unpaid social security contributions account for almost half of the "cashback."

\section{Distribution of "cashback": the profit-making model of labor agencies and scalpers}

The labor agencies and scalpers earn three types of fees from labor service companies. The first is the agency fee for recruitment, which is a charge for the processes of recruiting, organizing, and transporting services. The second is the "head fee," namely a charge that is calculated based on the number of workers provided by agencies and scalpers. The third is the "reward," by which the labor service companies could make up for the price gap between the paid agency fee and the increased market price. This "reward" is very flexible and can change from day to day. Due to the competition between labor service companies, it is imperative for them to dynamically adjust the reward to win over those labor agencies and scalpers downstream of the intermediary chain.

From the above analysis, it can be concluded that the profit-making models of the labor service companies, labor agencies, and scalpers are tightly linked with each other, interlocking into a coalition of interest. In this sense, the intermediary industry for recruitment has become one interest group shaping the labor market.

Figure 3 shows the money flowing along with factories, intermediary chain, and workers. The income of the labor service companies mainly includes the management fees and rewards from the factories as well as the interview fees and social security contributions of workers. Then, the labor service companies pay the agency fees, "head fees," and the rewards to the big scalpers. Likewise, the big scalpers pay the three kinds of charges to the small scalpers and then from small scalpers to labor agencies; however, the profit is diminishing along the intermediary chain. As a result, for workers who stand at the end of the chain, their share of "cashback" is determined by the length of the intermediary chain; the longer the chain, the less money they can get as "cashback." 


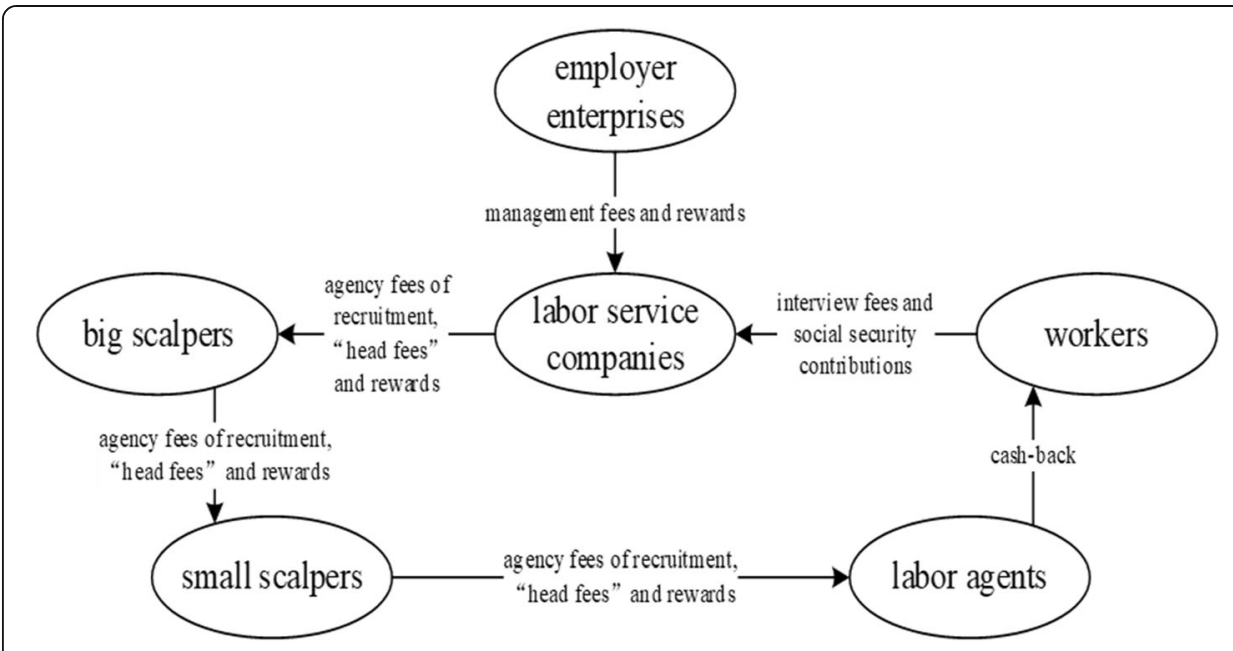

Fig. 3 The flow of money along "factories-intermediary chain-workers"

Risk of loss and flexible adjustment of labor service companies, labor agencies, and scalpers

For labor service company: "gambling probability" and "adjusting social security"

Despite their proven profit-making model, labor service companies are still exposed to the risk of profit shrinking, even the risk of loss when agency fees downstream go up during the busy season. During the busy season, although the labor service companies earn much more in management fees, the cost of recruiting one worker soars strikingly, sometimes higher than 5000 Yuan, which is far above the factory-paid management fees and rewards. However, to compete for reputation and market share, the companies have no alternative but to pay for the seasonal premium.

How then could labor service companies avoid losses and secure profits? Flexible profitability is the key, which is built on two strategies of labor service companies: gambling probability and adjusting social security. The first strategy is that under the constraints of the seasonal production, labor service companies attempt to compensate for the deficit in the busy season by increasing profits in the slack season. This strategy is possible because, on the one hand, the hiring cost in the slack season is much lower, and labor service companies are able to provide one worker at the cost of approximately 1500 Yuan, nearly one-third of that in the busy season. On the other hand, assuming an equal length of employment for all outsourced workers, even though labor service companies receive less management fees in the slack season than that in the busy season, the rewards in slack season are not necessarily less. The reason is that the reward is calculated based on the proportion of workforce demand that has been satisfied by labor service companies in the current quarter. Thus, while the management fees are low in the slack season, labor service companies can still earn profits with the much lower hiring cost and nearly equivalent rewards, which can even out their deficits in the busy season. However, it is still a game of "gambling probability" because it is difficult for labor service companies to bargain prices with factories and the downstream intermediaries. In the meantime, labor service companies cannot control management fees because of high worker turnover. Considering the considerable 
uncertainty in the hiring cost, management fees, and rewards, no labor service companies can forecast with confidence whether they are facing a loss or will "even-up" in this business. They must gamble probability.

The second strategy is that the labor service companies adjust their social security contributions for workers, thereby indirectly adjusting the "cashback" that they have to pay. As mentioned before, the primary sources of "cashback" are management fees, rewards, and social security contributions. Among the three, labor service companies can only control social security payment, and so use the social security contributions for workers as the means to adjust profit margin. In the busy season, labor service companies do not pay social security contributions for outsourced workers. Moreover, they prolong the probation of dispatched workers to reduce the total cost of social security, by which they could offer a higher "cashback" while avoiding the risk of loss due to the high cost of it.

\section{For labor agents and scalpers: maneuver for "cashback"}

Scalpers and labor agencies downstream of the chain are also exposed to the risk of loss because, in the busy season, despite their promise of a large sum of payments, labor companies tend to delay payment due to difficulties in capital turnover. Aiming to "grab off" as many workers as possible in the busy season, scalpers and labor agencies have to pay part of the "cashback" out of their own pockets in advance to secure their relationship with workers successfully. In some cases, however, they are facing deficits when money paid by the labor service companies afterward is far less than the "cashback" they have paid in advance. Then, what adjustment do these scalpers and labor agencies make to secure their share of profits? Their maneuver for "cashback" is the key.

If "cashback" is to blame for the shrinking profits of the labor service companies, it is the primary source of increasing profit margins for scalpers and labor agencies. For labor service companies, "cashback" functions as an expediency to recruit the workforce and reduce the turnover rate in the busy season. For scalpers and labor agencies, it is a way of making money. Because each time a worker returns to the labor market, he or she creates a potential opportunity for new income. Labor agencies and scalpers often encourage workers to quit once they reach the minimum requirement of the length of employment, and the workers who return to the labor market once again could be priced and sold.

Therefore, the scalpers and labor agencies manage to earn twice the agency fee on the same worker. Also, by this maneuver, they create an illusion of labor shortage in the market, which becomes an opportunity for them to drive up "cashback" and make more money. For seeking more profits, some of them even embezzle the "cashback" that should be distributed to workers and flee.

\section{Worker's role and action under the temptation of "cashback" Game of making "cashback"}

High "cashback" attract workers to engage in the game of making "cashback" with intermediaries. Some of these workers become the winners of the game by acutely 
identifying the means of access to higher "cashback" and implementing certain strategies of flexibility to earn it.

The experienced players of the game first choose a labor agency which has a good reputation in the business and offers higher "cashback." To secure the "cashback," the workers would ask the labor agency to provide a certification for the "cashback." If the labor agency does not pay the "cashback" in time as promised, these workers will threaten to expose this deceit on the Internet and pressure the labor agency to give back the money. Once obtaining a factory job, these workers only work there for the minimum required length of time to get the "cashback." Then, these workers quit and repeat the whole process again and again to earn more "cashback." In this way, these workers set up a collaborative relationship with labor agencies who offer a higher "cashback" to these regular clients.

However, new job seekers are not lucky. Uninformed about the rules behind the game, they often choose a labor agency at random and try their luck there. At first, the high "cashback" promised by the labor agency can be very tempting for the new job seekers, but when they return to the labor agency to demand the "cashback," they may confront two possible situations: first, the labor agency is closed, and the agent has fled; second, they receive only a small part of the "cashback." In the latter case, some of the unlucky workers insist on the full payment of the "cashback," but they may not get their money back, and some may receive retaliation.

\section{Workers' actions of right assertion}

Upon failing to get the "cashback," an experienced worker would neither "make trouble" with the labor agency nor seek to defend their rights but choose to leave away. They learn a lesson and become more circumspect when choosing from labor agencies next time. The reason why the experienced worker will not "make trouble" is that there are usually a few gangsters who garrison at the store of labor agency as a deterrent to troublemaking job seekers. It is also fruitless to safeguard their rights in most cases because the remediation procedures are often arduous and ineffective.

Generally, workers defend their rights by appealing to the authority, which requires workers to go through a set of procedures. The first step in the proceedings is to file a complaint with relevant materials, and the labor inspectorate will decide if they would take the case within 5 days. If the case is taken, the documents are supposed to be uploaded onto the system, and then an investigation would be launched. The worker would be notified of the result. If the worker is not satisfied with the result, he or she could request another administrative review by the supervisory commission. As sound as the procedures seem, the safeguarding of workers' rights is often blocked by these procedures because of the irregular or incomplete materials a worker provides. Mainly two aspects result in the flaws with these materials. First, "cashback" is given as only a verbal assurance, not appearing on the contract between the workers and labor service companies. Second, the "cashback" certification given to workers does not have any legal standing, and the invoice does not mention in detail that this money is used for "cashback" either. The authority has proven ineffective in defending workers' claims of "cashback." It can only serve as a mediator in the negotiation between the workers and labor agencies, and the workers are disappointed with the result. 
Even if the workers reveal that the "cashback" actually comes from the misappropriation of social security contributions, the government still has difficulties in enforcing justice. On the one hand, labor agencies and scalpers distribute "cashback" to workers, and there is no evidence that "cashback" comes from labor service companies which expropriate social security contributions. Moreover, their business flexibility makes it difficult for the government to supervise them adequately. On the other hand, there is no explicit legal provision to regulate the social security contribution for outsourced workers, not to mention the difficulty in distinguishing between labor outsourcing and labor dispatching, which jointly create a gray area for supervision. For labor service companies, one way to avoid supervision is to sign an agreement with the factories to rent workshops and equipment; thereby, labor service companies run production in name, while factories are still in control. Law fails to regulate labor outsourcing. An inspector told me the following:

Social security contributions of labor outsourcing cannot be supervised; rewards indeed come from social security contributions. Before, our front-line law enforcement is easy to monitor on labor dispatch, but after the dispatch control changes to 10 percent, it becomes outsourcing, there is no need to distinguish the bonus on the invoice clearly. All in a muddle, it is difficult to supervise. Now it becomes true dispatch and fake outsourcing. ${ }^{10}$

The workers have been put in a disadvantaged position in such circumstances. After the failures of arguing with the intermediaries and requesting intervention by the supervisory authority, the workers who have been stuck in a difficult situation start to lose hope. In extreme cases, desperate workers even choose to commit suicide.

\section{The institutional environment of the labor market}

The previous sections describe the operation of the labor intermediary chain through which labor is bought, exchanged, and transferred. While the labor intermediary chain is built on the model of global production, the production regime does not determine its birth and operation. Over the 40 years of reform and opening-up, the production regime has not changed much, but the current order of labor allocation has changed. What needs to be explained is how the institutional conditions that sustain global production are constructed, and what is the logic of action in the built institutional environment? We argue that the local government, workers, and factories together promote the creation of an institutional space conducive to the intermediary chain operation. Each is actively playing a role in strategically managing their own "flexibility" to continue to benefit from the existing production regime.

The protectionist bent of local government: law enforcement flexibility

Local government acquiescence to current labor market ecology is not because of its ignorance of the intermediary chain and "cashback" but rather a result of their compromise with difficulties in evidence collection and inspection. Behind the persistent existence of "cashback," the local government has two major concerns.

${ }^{10}$ Interview with a labor inspector (July 25, 2018). 
On the one hand, the government is afraid that the prohibition of "cashback" will hurt the local manufacturing industry and investment. Over the years, the practice of "cashback" has been familiar to local workers and has drawn tens of thousands of migrants to City W. With the lure of "cashback," thousands of workers are brought to factories to keep production running. Well-run factories bring more tax revenue, ${ }^{11}$ attract investment, and promote the local economy for the local government; downstream intermediary organizations gain a share of the profits from factories, making a prosperous human resources market. However, with the prohibition of "cashback," factories could not recruit enough labor force to maintain production, which will unsurprisingly damage the business of intermediaries and even lead to the depression of the entire manufacturing industry. Since strict law enforcement will cause workforce drain and factory relocation, the local government thus turns a blind eye to the practice of "cashback." A government official told the following:

The government could not bear business failures when corporate tax counts for a large proportion of government revenue. This is a nationwide problem. In previous years, labor agencies took some money from workers' social security, but there was no specified punishment measure according to the regulation. ${ }^{12}$

On the other hand, the local government insists that the governance of the labor market is not merely about regulating illegal intermediary organizations but also about maintaining social stability. Factories provide a lot of jobs, reducing instability caused by unemployment. In addition, some staff in intermediary organizations used to be gang members who were involved in illicit activities before joining the intermediary organizations. If the revenue of the labor business shrinks dramatically, it is extremely likely that they return to the gang activities and threaten social stability. Unexpectedly, as a labor control system, labor service companies also play a role in solving collective labor conflicts. Therefore, local officials have developed a set of flexible strategies to contain rather than punish labor service companies, limiting "cashback" within a certain range. Through flexible law enforcement, the local government has constructed a flexible institutional space for "cashback" practice.

\section{Outsourcing the risks of global production: employment flexibility}

The majority of factories in City W contract foreign orders and earn processing fees. This pattern of global production has three risks. First, seasonal fluctuation of orders requires the capability of mobilizing a large group of workers within a short period to work with high intensity and precision. Structural labor shortages and the skyrocketing demand for labor in the busy season make the human resource department very difficult to hire thousands of workers daily, and enterprises cannot afford the loss from massive defaults on orders caused by the lack of workers.

Second, by outsourcing labor recruitment, factories transfer the risk of labor disputes touched off by the mass dismissal of workers in the slack season. To balance profit changes in the season, factories build a flexible employment chain, namely "off-season

\footnotetext{
${ }^{11}$ According to the 2017 City W Statistical Yearbook, the value-added tax paid by industrial enterprises above the state's designated scale was 33.5 billion yuan.

${ }^{12}$ Interview with a government official (July 25, 2017).
} 
dismissal, peak-season hire," to deal with seasonal changes in labor demands. Via a flexible employment chain and the outsourced labor management, factories maximize their profits, reduce the risk of defaults, and avoid labor disputes.

Third, factories shift social responsibility to labor service companies via labor outsourcing. On the one hand, labor service companies need to take up responsibility when workers' rights are violated, such as with industrial injuries. On the other hand, when workers disagree on or are dissatisfied with wages and "cashback," factories shirk responsibility by saying that their wages have been transferred to labor service companies.

Thus, in addition to the labor process control, factories successfully establish an indirect labor control system by outsourcing the risks of employment to labor service companies. Especially in situations of "fake outsourcing, true dispatching," factories can control and exploit workers without receiving labor inspection. Notably, labor outsourcing is the immediate cause of "cashback," which shapes the organizational ecology of the current labor market.

\section{High atomization of workers: flexibility of mobility}

Workers themselves are essential in shaping the organizational ecology of the labor market. First, because rural migrant workers face many institutional barriers for urban integration and upward mobility, they are more likely to be overwhelmed by the air of pessimism about career prospects. It seems understandable for workers to earn extra money through job-hopping, which is the only available option they have. For most new-generation migrant workers, they are the victims of the production regime characterized by separated reproduction of migrant labor in the countryside. Their childhood was left behind in villages without the parents' company; unlike the older generation, they have little experience in agricultural work and bear no family responsibility (Wang and Huang 2014). These workers have left rural villages and are not willing to return there. They prefer living in cities for a long time, despite earning a minimal living.

Moreover, workers' locked social status, inner anxiety, and aspirational disillusionment have spawned consumerism. Many workers expressed that job-hopping for "cashback" serves the purpose of short-term consumption rather than long-term career development. In such situations, the temptation of "cashback" exceeds the long-lasting protection brought by social security. Thus, some workers who are aware that labor service companies do not pay social security contributions are still willing to cooperate with them and voluntarily sign an agreement to trade social security contributions for the "cashback" money. The temporary happiness of consumption is rapidly giving way to uncertain futures and emptiness in life.

Lastly, cooperation and solidarity are absent among workers. In most cases, they are unable to organize collective actions against intermediary organizations' exploitation and tend to hold an indifferent view about the infringement of the rights. As individuals, instead of a united group, workers are doomed to subordinate themselves to the domination of intermediary organizations. Job-hopping for "cashback" also prevents workers from developing friendships and working-class solidarity.

Individual workers without any social network become the cash cows of intermediary organizations. Their illusory dream of wealth, longlines, and mobility are the keynotes of the organizational ecology of the labor market. 
In sum, due to local protectionism, the local government is not willing to regulate the intermediary chain of migrant labor but take advantage of flexible law enforcement to tacitly allow the existence of "cashback." To outsource the risks of employment, factories are heavily dependent on intermediary organizations to supply and control labor forces and are willing to pay higher costs in exchange for flexible labor. Because of the lack of solidarity, workers are unable to resist any violation of labor rights during the operation of intermediary organizations. The only option is to hop jobs to fully make use of the flexibility of mobility and earn a short-term income. The strategy of flexibility serves workers' short-term consumption but sows the seeds of the hidden hazards for their long-term career development.

\section{Conclusion and discussion}

In this article, we have shown the employment chain and the institutional environment in the organizational ecology of the labor market. To fulfill the dual requirements of flexibility and large labor force, factories outsource the hiring of formal workers to labor service companies, which organize, select, and supply workers to factories. Responding to seasonal production and labor shortages, service companies cooperate with other downstream intermediary organizations to complete recruitment tasks. As a result, labor service companies, scalpers, and labor agencies with different qualifications and sizes form a multilevel subcontract chain of labor recruitment. "Cashback" is the core to keep the whole chain functioning smoothly. First, by manipulating "cashback," intermediary organizations are able to coordinate with each other to create a large pool of outsourced workers to sustain seasonal production despite labor shortages. Second, "cashback" is the foundation of the profit-making model and the profit-adjusting mechanism of intermediary organizations. Intermediary business operations based on distributing "cashback" money masks the reality that the benefits of workers have been eroded layer by layer, and to some extent, increases factories' labor cost and turnover rate as well. Regarding the institutional environment, although the current organizational ecology of the labor market would hurt both factories' and workers' long-term interests, the intermediary chain nonetheless prospers in such a favorable institutional environment built jointly by the government, factories, intermediary organizations, and workers.

This article makes four contributions. First, this article has revealed that intermediary organizations are the key to resolving the tension between structural labor shortages and the continuous operation of the global production. Through the recruitment chain and "cashback," intermediary organizations mobilize and organize a flexible labor force, creating a vast labor pool to serve the continuous operation of the global factories. However, maintaining the flexible labor sacrifice workers' the long-term wellbeing. While it seems that "cashback" indicates that workers have increased labor-market bargaining power, in fact, it is an infringement of workers' rights. In the current organizational ecology of the labor market, vulnerable workers have gradually lost longterm protection, opportunities for upgrading skills, and the bargaining power in the labor market, eventually being reduced to cheap labor in the system of flexible employment.

Second, this study points out that there remains a complicated relationship between the market and society. On the one hand, a labor shortage could be a sign of a 
countermovement for labor protection. Workers "vote with their feet" to resist the over-commodification of labor. On the other hand, the market has established a new form of flexible pricing system to re-commodify labor with the assistance of intermediary organizations. Embedding and dis-embedding are in the process of dynamic interaction. Of concern are various factors that contribute to this interaction, that is, cultural, historical, and institutional contexts in which the labor market is embedded. In this research, the local government, factories, intermediaries, and workers are the actors whose interactions create conditions for the re-commodification of labor through managing "flexibility." While they take advantage of the flexibility to satisfy the shortterm goals of flexible production, they risk economic and social stability in the long term.

Next, this article has illustrated the significance of organizational ecology and the control mechanism of the labor market. Marx (1975) emphasizes that the secret of capital making profits is in the sphere of production rather than in labor purchase, and it is not the labor force that capitalists buy in the market but labor. In this regard, a considerable body of sociological work has generated critical insights into the politics of production, but the debate on the labor process only focuses on the sphere of production and rarely discusses how workers are recruited into factories and become the subjects of control and exploitation. Since the 1970s, a decentralized production system has been established and widely implemented, and labor control has evolved from direct bureaucratic control to agent control. One crucial part of agent control is to take full advantage of the labor market by constructing diverse employment relationships to achieve the flexible accumulation of capital. To realize agent control, intermediary organizations play an indispensable role. Therefore, it is essential to investigate how the behaviors and strategies of intermediary organizations influence the labor market and what their social and economic bases are.

Finally, this article has some practical significance to the governance of the labor market. The enormous profits of the labor intermediary chain are from the labor outsourcing system. The prevalent phenomenon of "fake outsourcing, true dispatch" results from the narrow definition of labor dispatch by law. It is expected that strong cases of "fake outsourcing, true dispatching" revealed in this research could trigger some thinking and actions of relevant lawmakers and law enforcement officers.

Acknowledgement

N/A.

Availability of data and material

We have three data sources. First, field work on labor market in W city conducted from May, 2018 to November 2019. Interviewees and organizations were contacted through personal network and snowball methods. Second, we did indepth interviews with HR managers from factories, intermediary organizations, officials from Human Resources and Social Security Bureau. Third, statistical data was provided by public report (Report on the Supply and Demand Analysis of Human Resource) and confidential official authorities.

Authors' contributions

ZL designed the study and establish the theoretical framework. JZ collected data and contributed to data analysis. Both authors read and approved the final manuscript.

Funding

The authors declare funds from Fujian Province Social Science Planning (CN) FJ2017C050. 
Received: 4 March 2020 Accepted: 26 May 2020

\section{Published online: 18 June 2020}

\section{References}

Autor, D.H.2007.Studies of labor market intermediation: introduction. Paper Presented at the NBER Conference on Labor Market Intermediation in May of 2007.

Autor, D.H. 2009. Studies of Labor Market Intermediation. Chicago: University of Chicago Press.

Burawoy, M. 1979. Manufacturing Consent. Chicago: University of Chicago Press.

Cai, F. 2010. Demographic transition, demographic dividend, and Lewis turning point in China. Economic Research Journal 2010 (4): 4-13.

Cai, F., and M. Wang. 2005. An economic analysis of "peasant laborer shortage" based on the Pearl River Delta survey. Social Sciences in Guangdong 2005 (2): 5-10.

Granovetter, M. 1973. The Strength of Weak Ties. American Journal of Sociology 78 (6): 1360-1380

Granovetter, M. 1974. Getting a Job: A Study of Contacts and Careers. Cambridge: Harvard University Press.

Huang, Y. 2012. The "Making out" Game outside the factory: a case study of "making out" production in the Pearl River Delta area. Sociological Studies 2012 (4): 187-203-245-246.

ILO. 2002. Decent Work and the Informal Economy. Geneva: International Labor Conference 90th Session, Report VI, ILO.

Lee, C.K. 1995. Engendering the worlds of labor: women workers, labor markets, and production politics in the South China economic miracle. American Sociological Review 60 (3): 378-397.

Liu, D. 2014. Causes,Operating mode and regulatory strategies of "fake outsourcing and real dispatch.". Lanzhou Academic Journal 2014 (2): 162-167.

Liu, D. 2016. The order of a mobile society: Studies on organization and group behaviors of Yi People in Pearl River Delta areas. Beijing: China Minzu University Press.

Liu, L., and F. Cui. 2012. Labor relations in the transitional society: Characteristics and trends. Journal of Sun Yat-Sen University (Social Science Edition) 2012 (3): 151-161.

Liu, L., X. Wan, and Y. Zhang. 2006. Institution absence and labor shortage: Study on the "Famine of peasant workers.". China Industrial Economy 2006 (8): 45-53.

López-Sanders, L. 2014. Embedded and external brokers: the distinct roles of intermediaries in workplace inequality. American Behavioral Scientist 58 (2): 331-346.

Marx, K. 1975. Capital:Volume One. Beijing: People's Publishing House.

Meng, J., and Y. Li. 2013. The evolution of labor commodification and labor relations since the Reform Movement: Perspectives from Polanyi and Marx. Open Times 2013 (5): 74-106.

Polanyi, K. 2006. The Great Transformation: The Political and Economic Origins of Our Time. Hangzhou: Zhejiang People's Publishing House.

Pun, N., and A. Koo. 2015. A 'World-class' (labor) camp/us: Foxconn and China's new generation of labor migrants. Positions: Asia Critique 23 (3): 411-436.

Roediger, D.R. 1991. The Wages of Whiteness: Race and the Making of the American Working Class. New York: Verso.

Shen, Y. 2006. The social transformation and reformation of the Chinese working class. Sociological Studies 2006 (2): $13-36+243$

Stovel, K., and L. Shaw. 2012. Brokerage. Annual Review of Sociology 38: 139-158.

Wang, C. 2001. Social identity of the new generation of Rural Hobo and merger of urban and rural. Sociological Research 2001 (3): 63-76.

Wang, J., and B. Huang. 2014. The left-behind experience and job mobility of the New workers: how does the system of migrant workers jeopardize itself? Chinese Journal of Sociology 2014 (5): 88-104.

Wu, Y., and F. Cai. 2006. Informal employment in urban China: size and characteristics. China Labor Economics 2006 (2): $67-84$

Wu, Z., and B. Zhang. 2008. Discussion on the issue of labor dispatch. China High Technology Enterprises 2008 (8): $142-144$

Xiang, B. 2012. Global Body Shopping. Beijing: Peking University Press.

Xie, D. 2013. Rethinking the position of legal terms on labor dispatch in China. Contemporary Law Review 2013 (1): 119-125.

Xie, F. 2007. Capitalist labor process: the transition from Fordism to Post-Fordism. Journal of Renmin University of China 2007 (2): 64-70.

Xie, G. 1989. A comparative historical review on the outsourcing system. Taiwan: A Radical Quarterly in Social Studies 2 (1): 29-70.

Zheng, G., H. Sun, and X. Wan. 2015. From "Making out" game to "Everyone is boss": Labor control in informal employment. Sociological Studies 2015 (3): 170-195+245.

Zhou, G. 2012. On difficulties of transforming labor dispatch into outsourcing. China Labor 2012 (11): 14-17.

\section{Publisher's Note}

Springer Nature remains neutral with regard to jurisdictional claims in published maps and institutional affiliations. 